Dr. Jordan was justified in regarding it as representing a distinct family. Of general interest the specimen certainly was, however, from its grotesque appearance. But the feature which gave it especial value to the student was its resemblance to a shark of the Cretaceous period, Scaphanorhynchus, generally assumed to be extinct. Was it possible, then, that this Cretaceous shark was still living in Japanese waters? And if this were true, might it not occur in other deep-sea regions, like its more ancient relative, Chlamydoselachus? Thus we find that Dr. Arthur Smith Woodward, of the British Museum, commenting (1899) upon Mitsukurina, is distinctly of the opinion that the new genus was but a synonym for the Cretaceous shark, and he gives the evidence in favor of this view in the Annals and Magazine of Natural History (7), Vol. III., pp. 487-489, and makes out a fairly convincing case of identity. Nevertheless, we have to admit that the characters of the fossil shark are as yet too imperfectly known to warrant a definite judgment, and the safer course, therefore, is to acknowledge for the present the validity of the name Mitsukurina.

The note in the Japanese paper announces that more specimens of this shark have been taken, and we have promise, accordingly, that better anatomical data may be looked for. For one thing it now appears that the specimen first studied was an immature one, no examination of the soft parts having been made. The latest specimen in the hands of Mr. Owston measures, mirabile dictu, about twelve feet in length and its weight is estimated as between four and five hundred pounds. This extreme size, it will at once be seen, ranks this shark as one of the largest members of deep-water ichthyic fauna, and it is possibly the most formidable member of its community.

The depth at which the specimen was taken is not stated, but from the conditions of fishing near Numazu, the fish was apparently taken in water deeper than three hundred fathoms. As a symptom of its living at a great depth one notes in the latest description of the fish, that its 'flesh and skeleton are extremely limp, folding like a wet rag.' The color of the fresh specimen is described as 'light reddishbrown, the fins darker brown; nuchal region a little darker, and belly paler.'

\section{Bashford Dean.}

\section{EARLY INSTANCE OF TANGIBLE LIP-READING.}

AN interesting feature of the autobiography of Miss Helen Keller is the account by her teacher, Miss Sullivan, of her patient efforts to train her young pupil to receive and communicate ideas by tangible lip-reading. Most persons regard the education of blind deafmutes as a development of modern philanthropy, and it will surprise many to learn that the method of tangible lip-reading was invented nearly two hundred and thirty years ago.

Bishop Burnet, the fampus English historian and theologian, in a letter dated Rome, December 8, 1685, and addressed to the eminent scientist Hon. Robert Boyle, wrote as follows:

There is a minister of St. Gervais-Mr. Gody - who hath a daughter that is now sixteen years old. At a year old the child spoke all those little words that children begin usually to learn at that age, but she made no progress; yet this was not observed till it was too late, and as she grew to be two years old they perceived then that she had lost her hearing, and was so deaf that ever since though she hears great noises yet she hears nothing that one can speak to her. But the child hath by observing the motions of the mouths and lips of others acquired so many words that out of these she has formed a sort of jargon in which she can hold conversations whole days with those that can speak her own language. I could understand some of her words but I could not comprehend a period [sentence]; for it seemed to me a confused noise. She knows nothing that is said to her unless she seeth the motion of the mouths that speak to her, so that in the night when it is necessary to speak to her they' must light a candle.

Only one thing appeared the strangest part of the whole narrative. She hath a sister with whom she has practiced her language more than with any other; and in the night, by laying her hand on her sister's mouth she can perceive by that what she says and so can discourse with her in the night. It is true her mother told me this 
did not last long, and that she found out only some short period in this manner, but it did not hold out very long. Thus this young woman hath merely by a natural sagacity found out a method of holding discourse that doth in a great measure lessen the misery of her deafness. I examined this matter critically, but only the sister was not present, so that I could not see how the conversation passed between them in the dark.

The bishop's language will be clearer if we replace his word 'period' by the word 'sentence.' This passage occurs in a volume entitled 'Some Letters Containing an Account [of travels] in Switzerland, Italy [and] Germany in 1685 and 1686,' by Gilbert Burnet, London, 1687 (another edition, 1724), 1 Vol., 8 vo.

\section{Henry Carrington Bolton.}

\section{MARY LOUISE DUNCAN PUTNAM.}

Mrs. Putnam is dead. To those of us who saw her recently, active and happy, the news comes as a shock. But, for her, the end was beautiful; in the midst of her life interests, without shrinking or suffering, at the close of a day of work, she lay down to rest.

Mary Louise Duncan was born at Greencastle, Pa., September 23, 1832 . Her father, Joseph Duncan, was, at the time, the only Congressman from Illinois, with his home at Jacksonville. Later he was Governor of Illinois and was influential in shaping the trend of affairs in what was then the Far West. On her mother's side also Miss Duncan was of distinguished ancestry, being the great-granddaughter of that brave woman, Hannah Caldwell, of Revolutionary fame. In her father's home and at Washington, Miss Duncan enjoyed every opportunity and came into contact with men and women who planned and carried out great enterprises. In 1854 she married Charles E. Putnam, of Saratoga Springs, New York, and the young couple at once removed to Davenport, Iowa, which was, from that time on, their home. Mr. Putnam was a man of brilliant mind and talent, who, as a lawyer, soon won name, fame and influence in the new home.

Through her-life Mrs. Putnam was actively interested in every good work. Her connec- tion with many public and private enterprises deserves mention. But for us her relation to the Davenport Academy of Sciences is of chief importance. Mrs. Putnam was the mother of eleven children; she was devoted to the interests of each and all; with keen sympathy she entered into every child plan of work or play-the garden, the printing press, the family newspaper, the home dramatic performances. In every device of her children she found some helpful stimulus. She was more than an ordinary mother; she was the companion and confidant of each of her flock. So when her oldest child, a boy of fourteen, longed to join the newly founded Academy of Sciences, he demanded that the sharer of his joys, his mother, should also join. She was the first woman member. Joseph Duncan Putnam was a remarkable boy. At fifteen he was the secretary of the academy; before he was a man in years he was known by all the leaders in entomology; at twentyfive he was a recognized authority on some of the least known groups, of insects; at twenty-six he died. His ideals for the academy, to which he was absolutely devoted, were high. He urged permanence-a building, a publication, an exchange and contact with the outside world of science. He lived long enough to see the building and to know that the printed Proceedings of the academy were prized at home and abroad. In all his work and plans his mother stood ever near. When money was necessary she canvassed the city; when people would not give, she planned and carried out public meetings, lectures, entertainments; in some way, in spite of discouragement and rebuff, she won the day.

And when her son died she devoted herself to rearing his perpetual monument, in the academy. Through dark years, which would have daunted all but a mother's love, she has toiled, and she has succeeded. The academy lives and will live. Through her interest a publication fund, memorial to her son and her husband, was secured, and the Proceedings have been continuously published. The volumes contain important contributions in all fields, but prominent among them are those 